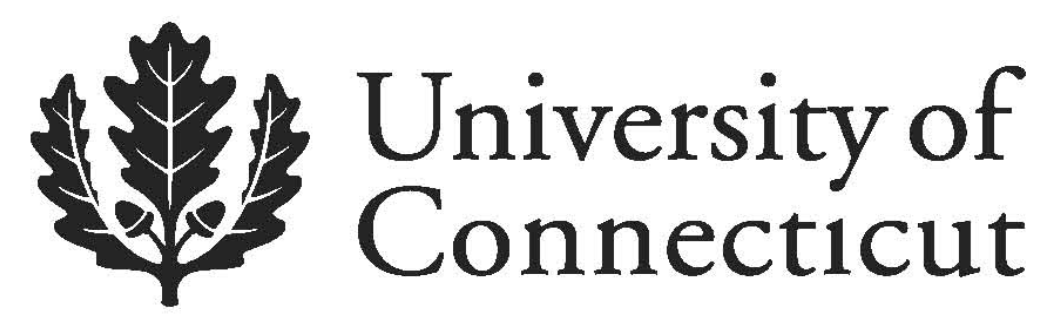

Department of Economics Working Paper Series

\title{
Dispute Resolution in Ottoman Courts: A Quantitative Analysis of Litigations in Eighteenth Century Kastamonu
}

\author{
Metin M. Coşgel \\ University of Connecticut \\ Boğaç A. Ergene \\ University of Vermont
}

Working Paper 2012-33

September 2012

365 Fairfield Way, Unit 1063

Storrs, CT 06269-1063

Phone: (860) 486-3022

Fax: (860) 486-4463

http://www.econ.uconn.edu/

This working paper is indexed on RePEc, http://repec.org 


\section{Dispute Resolution in Ottoman Courts:}

\section{A Quantitative Analysis of Litigations in Eighteenth Century Kastamonu}

Metin M. Coşgel and Boğaç A. Ergene

Abstract: We use data from the court records (sicils) of the Ottoman town of Kastamonu in the late seventeenth- and eighteenth-centuries to study the basic characteristics of litigants and the determinants of plaintiff's chances of winning at trial. The results show that the trial outcome was influenced by the gender, elite status, religion, and religious markers of litigants. The results challenge some of the widely held presumptions about dispute resolution in Ottoman courts, such as Weber's claim about arbitrariness of the judges' decisions and the perception in Ottoman legal scholarship that the court may have subscribed to an egalitarian legal ideology. Kastamonu judges made decisions that can be grasped by the tools and concepts of modern scholarship on dispute resolution, and their decisions displayed systematic patterns that are consistent with those identified by quantitative analysis of court outcomes in modern societies.

JEL codes: $\mathrm{H} 1, \mathrm{~K}, \mathrm{~N} 45$

Key words: court, litigation, trial, dispute resolution, selection effect, Ottoman Empire

Metin M. Coşgel is Professor of Economics, University of Connecticut, Storrs, CT 06269-1063, Ph: (860) 486-4662, Fax: (860) 486-4463, e-mail: metin.cosgel@uconn.edu

Boğaç A. Ergene is Associate Professor of History, University of Vermont, 133 Prospect St., Burlington, VT 05405; e-mail: Bogac.ergene@uvm.edu 


\section{Dispute Resolution in Ottoman Courts:}

\section{A Quantitative Analysis of Litigations in Eighteenth Century Kastamonu}

Courts have been essential in the resolution of legal disputes throughout history. Even though only a small proportion of all disputes may wind up in formal litigation, the ability of courts to adjudicate effectively is crucial in reducing the degree of uncertainty and the loss of welfare in social interaction and market exchange. The manner in which courts resolve disputes has additional implications for economic change and sustainable economic growth, as noted long ago by Weber and in more recent scholarship on legal origins, law and finance, and comparative analysis of legal traditions. ${ }^{1}$ As Ma and van Zanden (2011) have argued, however, much of the recent literature has focused narrowly on western European legal systems and devoted little attention to systematic analysis of non-western legal traditions. Particularly rare has been quantitative analysis of dispute resolution in Islamic courts.

This article aims to fill this gap by studying litigations in Ottoman courts. We use data from the court records (sicils) of the town of Kastamonu in northern Anatolia, from the late seventeenth and the eighteenth centuries. Ottoman court records typically give detailed information about the nature of each case considered, including its result, and the identities of litigants. Using this information, we examine quantitatively the basic characteristics of court participants, such as their distribution according to gender, religious status, and socioeconomic

\footnotetext{
${ }^{1}$ See, for example, Glaeser and Schleifer (2002), La Porta et al, (1998), Ma and van Zanden (2011), and Weber (1978).
} 
characteristics. We also run regression analysis to determine the factors that contributed to the likelihood of the case being ruled in favor of the plaintiff. ${ }^{2}$

Our findings are closely related to the scholarship on the nature and operations of Islamic courts of law. The modern academic literature on Ottoman courts developed to a significant extent in reaction to the Weberian notion of "kadijustiz," which portrayed the operations of Islamic courts as arbitrary and potentially corrupt (Weber 1978, 891-2, 897, 976, passim.). The Weberian characterization of the Islamic courts remained dominant in Western scholarship until the second half of the twentieth century (Peters 2005, 70; Powers 2002, ch. 1; Jennings 1978). Most modern students of Ottoman courts, however, emphasized the predictable nature of the court, the professionalism of its magistrate (kadi), and the fairness of its operations. In this study we provide a quantitative assessment of some important observations made by these researchers.

Our analysis is also related to the general law and economics literature on dispute resolution. ${ }^{3}$ A key insight in this literature is that disputes do not always end up in court. Since courts are costly and verdicts uncertain, parties may settle outside of court if they expect costs of going to court to be greater than benefits. It follows from this selection effect that only cases that are close to the decision standard will be litigated and that plaintiff victories in trials will tend towards fifty percent, known as the benchmark hypothesis of this literature (Priest and Klein, 1984). A large theoretical and empirical literature has developed to identify the conditions under which this hypothesis would hold true and the factors that would cause outcomes to vary systematically. Our paper provides an analysis of these issues in a historical context.

\footnotetext{
${ }^{2}$ See below for a discussion on the appropriateness of using Western legal terminology in the Ottoman context.

${ }^{3}$ For reviews of this literature, see Cooter and Rubinfeld (1989) and Miceli (2009, Chapter 8).
} 
Yet another literature that is related to our paper is the quantitative analysis of litigations in history and the relationship between dispute resolution and other economic variables. Economic historians have used court records to study such wide ranging subjects as the evolution of conflict and cooperation on the Australian frontier, the relationship between litigation and credit in an urban English community, and the association between defaults on small debts and the state of the labor market. ${ }^{4}$ By contributing results based on Ottoman courts, our analysis will facilitate comparisons with other societies and time periods.

The next section will put this study in context by offering a brief discussion of previous arguments on Ottoman courts, followed by a survey of the law and economics literature on dispute resolution in courts. We then describe our data and provide summary statistics on the cases and participants included in our data. Turning next to a quantitative analysis of court outcomes, we examine the factors that influenced the success of the plaintiffs. We conclude with a discussion of our main results and their implications for Ottoman legal practice.

\section{JUSTICE IN OTTOMAN COURTS}

Although the quantitative analysis presented in the article is fairly new in the context of Middle Eastern history and Ottoman legal studies, the questions that we address are not entirely novel. Most students of Ottoman court records have emphasized the professionalism and relative impartiality of the courts' operations in their attempts to explain the political and administrative legitimacy of the Ottoman government. The secondary literature on the Ottoman court, as Meshal (2010: 212) has recently observed, suggested that this institution operated as "as equitable venues where 'a woman or a slave' could win rulings against amirs...where dhimmis

\footnotetext{
${ }^{4}$ Khan (2000), Muldrew (1993), and Johnson (1993). See also Ma and van Zanden (2011) for the relationship between the legal system and long-term economic change.
} 
preferred to have their cases heard." In this view, the early-modern court, which functioned almost as a semi-independent branch of the government, was instrumental in keeping the provincial power-holders and non-judiciary state functionaries in check and limiting their exploitative tendencies (Barkey, 1994 and 2008; Cohen, 1994; Gerber 1988 and 1994; Hanna 1995; İslamoğlu-İnan, 1994). By doing so, the legal system guarantied the welfare of the common men and women and, thus, ensured their beliefs in the justice and legitimacy of the Ottoman system of government (İnalcık 1986 and 1988; Jennings, 1978 and 1979; Singer, 1994).

In general, the works that constitute this literature exhibit a few theoretical and methodological flaws. ${ }^{5}$ Particularly relevant for the concerns of this article is the fact that their assessments of the courts' decisions are almost exclusively based on impressionistic observations. While we too are interested in the types of questions raised in the existing literature on Ottoman courts, we believe that a more systematic and quantitatively-ambitious approach might yield different conclusions. ${ }^{6}$ Without delving into the difficult question of what it means for a court to be "fair" in the context of eighteenth-century Ottoman Anatolia, we propose in this

\footnotetext{
${ }^{5}$ Theoretically, this scholarship suffers from a state-centric bias, still prevalent in Ottoman studies. It represents the provincial court primarily as an extension of the imperial government and interprets its functions in the context of an idealized and undifferentiated state-society polarity. Only in the last decade or so researchers have begun to pay greater attention to local dynamics in the interpretation and practice of law and developed more nuanced understandings of the court's functions in provincial contexts (Agmon, 2005; Peirce, 2003; Ergene 2003). In this article we do not explicitly focus on this topic.

${ }^{6}$ To our knowledge, there are only two studies (Ergene, 2008; Kuran and Lustig, 2012) on Ottoman court records that utilize a predominantly quantitative approach in attempting to answer related questions and they both challenge some important assumptions prevalent in the literature.. The present study differs from these two in major ways. The article by Ergene (2008), which also examines eighteenth-century court records from Kastamonu is a preliminary study, based on a limited sample, that lacks the quantitative sophistication exemplified in the best examples of quantitative legal research. The article by Kuran and Lustig (2012), on the other hand, explores primarily commercial litigations in Istanbul courts. In addition, the theoretical foundations of the present article and the socio-economic categories of analysis utilized in it are significantly different from those found in Kuran and Lustig's study. We thank Timur Kuran and Scott Lustig for sharing their article with us before its publication.
} 
article a set of conceptual tools and analytical procedures that can help us identify how different gender, socioeconomic, and religious groups performed in the legal arena of the court in one early-modern provincial context.

\section{RESOLUTION OF DISPUTES AT TRIAL}

The issues raised in this article about the operations of Ottoman courts are also closely related to those studied in the broader theoretical and empirical literature on dispute resolution. A key question in the law and economics literature on trials has been to determine the factors affecting the plaintiff's chances of winning the suit. In a seminal article on the topic, Klein and Priest (1984) formulated the hypothesis that under certain conditions plaintiff win rates at trial should tend towards fifty percent as the fraction of cases that go to trial approaches zero. This is based on a simple selection effect that follows from the observation that cases that go to trial are not a random selection of all suits. Rational litigants would likely settle cases in which one side is likely to be a clear winner, and they would go to trial only in difficult and uncertain cases for which there is greater disagreement. As a result, the cases that go to trial would likely be "toss up" ones which are won about half the time by the plaintiff and half by the defendant.

Studying plaintiff win rates in various datasets, researchers have found that actual rates can vary systematically from the hypothesized limiting case of fifty percent. ${ }^{7}$ These results may still be consistent with the underlying selection hypothesis because the variation across cases could simply be caused by violation of the assumptions behind the simple model. To reconcile the results found in the empirical literature with the selection hypothesis, Kessler, Meites, and Miller (1996) have proposed a "multimodal approach" that considers several characteristics of

\footnotetext{
${ }^{7}$ For a summary of these cases, see Kessler, Meites, and Miller (1996: 238-41). See also Cooter and Rubinfeld (1989), Kessler and Rubinfeld (2007), and Miceli (1999) for reviews of this literature.
} 
cases that could affect the plaintiff win rates. More specifically, they show that plaintiff win rates can vary across cases if, for example, one party has higher stakes in the case than the other, if they have different attitudes towards risk, or if one party has private information about his or her chances at trial. Such factors may affect the cost or benefit of winning at trial for reasons that are unrelated to the specific case. To see this, consider the possibility of asymmetric stakes. If, for example, the reputational stakes are greater to the plaintiff than the defendant, the plaintiff is likely to have a greater degree of success because he or she would have more to lose from the litigation and therefore likely offer enough to settle the case. Hence litigation would be more likely in cases where the plaintiff has a high probability of winning, indicating that in such cases the plaintiff win rates would on average be higher than fifty percent.

Siegelman and Waldfogel (1999) have extended empirical analysis of plaintiff win rates by identifying three characteristics of the litigation environment that can explain the observed trial outcomes. These characteristics are the decision standard, parties' ability to estimate the quality of their cases, and the degree of stake asymmetry across parties. As we discuss in more detail below, by operationalizing these characteristics in the litigation environment of Ottoman courts we are able to explain variations in the plaintiff win rates in Kastamonu in the eighteenth century.

\section{OTTOMAN COURT PROCESSES AND RECORDS}

The litigations studied in this article are found in the court registers of Kastamonu, an Ottoman town located in north-central Anatolia, covering the period between 1084/1673 and 1221/1806. ${ }^{8}$

\footnotetext{
${ }^{8}$ The court records of Kastamonu are fairly complete for the late seventeenth and eighteenth centuries, making them suitable for our analysis. We studied the microfilm copies of these documents that are deposited in the National Library in Ankara, Turkey.
} 
The town was the administrative center of the Kastamonu sub-province (sancak). The court's jurisdiction included about forty quarters in the town as well as the seventy-five or so surrounding villages. ${ }^{9}$ Contemporary tax records give the population in the jurisdiction as between 3,500 to 4,000 households. Early nineteenth-century European travelers put the population of the town around 12,000 (Heywood 1978), which suggests that Kastamonu was a medium-sized urban center according to contemporary standards. The population of the town and surrounding villages was predominantly Turkish-speaking Muslims; according to our sources, the share of the non-Muslims (primarily Christians) did not exceed fifteen percent of the population. The town was not a major commercial center in the eighteenth century. Its main economic activity was agricultural production and animal husbandry. Sources also indicate the existence of a variety of manufacturing activities, although none of these, perhaps with the exception of copper-ware production, are particularly noteworthy (Ergene 2003).

The court enforced the Hanafi interpretation of the Islamic law, which was the official legal school in the Ottoman Empire, as well as the sultanic law-codes (sing. qanunname). The magistrates (sing. $k a d l$ ) were usually not native to the region; they were appointed for twelve- to sixteen-month terms in order to limit the possibility for them to establish strong and potentially corrupting relationships with the inhabitants of their jurisdictions. However, other court functionaries, such as deputy magistrates (sing. naib), scribes (sing. katib), or summon-servers (sing. muhzir), were often recruited from the local community. Furthermore, the names of a select group of individuals appear in the court records as "witnesses to proceedings" (şuhudülhal), although they do not seem to be the only ones to serve in that capacity.

\footnotetext{
${ }^{9}$ These numbers varied slightly during the eighteenth century.
} 
The court was presided by the $k a d l$, whose responsibility was to interpret the law and pronounce verdicts. He did not usually investigate the disputes but based his decisions on the statements of and evidence provided by the litigants. One of the critical functions of the kadl in the litigation process was to decide who bore the burden of proof. This was supposed to be the party whose contention was contrary to the initial legal presumption. The burden of proof could be placed on the accuser or the accused based on the nature of their claims and responses. In an unpaid-debt dispute, for example, the $k a d l$ would first hear the claim made by the accuser (the alleged creditor) and then demand the accused (the alleged debtor) to respond to the accuser's contention. If the accused denied the debt claim, the $k a d l$ would require the accuser to provide evidence to support his claim since the legal presumption would be that the alleged debtor was free from debt. On the other hand, if the accused acknowledged the original debt transaction but also stated that the debt had already been paid before the trial, than the court would require her/him to prove her/his claim, since in this situation it would be the accused who would be making a contention against initial legal presumption.

In either case, the kadl would rule for the parties who assumed the burden of proof without further investigation, if they could bring to court credible evidence. ${ }^{10}$ In other words, the $k a d l$ would not give a chance to their opponents to provide evidence that might support their own positions after those who assumed the burden of proof provided the court with credible evidence. On the other hand, if the parties who assumed the burden of proof failed to produce any evidence, or if their evidence were deemed by court untrustworthy, then the kad $\imath$ would ask their opponents to take an oath to the truthfulness of their allegations. If they did so, the kad $\imath$ would

\footnotetext{
${ }^{10}$ In a great majority of the cases, the evidence provided to court consisted of witness testimonies by two or more male, adult, Muslims.
} 
rule for them. If not, he would rule for those who assumed the burden of proof but could not provide evidence, sometimes after forcing them to take oaths as well. ${ }^{11}$

At this juncture a terminological clarification may be necessary. In Ottoman legal parlance the terms that were used to refer to litigants are "müdde ' $\imath$ " (literally, "one who makes a claim") and "müdde 'a 'aleyh" (literally, "against whom a claim is made"). It is not technically correct to translate these terms as "plaintiff" and "defendant," since the "claim" in question does not refer to the initial complaint or accusation but one that is required to be proven by evidence. The label "müdde ' $i$ " denotes the litigant, whether he or she brought the case to court or not, who bears the burden of proof. Since the accused parties could also assume the responsibility of proving their cases, as we saw, they could be the "müdde 'iyun" (pl. of müdde 'i). Although the labels "plaintiff” and "defendant" are not used in Islamic/Ottoman legal practice, we employ these terms in our analysis in order to make our results comparable to those obtained in other contexts. In what follows, the term "plaintiff" simply refers to the party who made the original allegation of injury and the "defendant" to the party who found him/herself in the position to respond to this claim. ${ }^{12}$

The following case entry is an example of the case entries that constitute the source material of this study:

\begin{abstract}
Mustafa Ağa ibn (son of) Elhac Hüseyin Ağa of Kübceğiz quarter made the following statement against Ali Beşe ibn Mehmed: "Four days ago, Saime bint (daughter of) Ali, who is currently present in the court, agreed to sell me her house located in Kübceğiz quarter in return for 180 guruş. Yet when I now try to give 180 guruş to Saime and occupy the aforementioned house,
\end{abstract}

\footnotetext{
${ }^{11}$ Some cases were resolved easily when the accused acknowledged the validity of the allegations directed against them.

${ }^{12}$ Most cases in our sample are simple litigations, which involved straightforward accusations by plaintiffs followed by defendants' denials. This is why most plaintiffs were designated as müdde 'iyun in these cases, although this was not a legal requirement.
} 
Saime resists and the aforementioned Ali Beşe objects. I want them to be questioned and their intrusion be stopped."

Upon questioning, Ali Beşe denied the agreement (between Mustafa Ağa and Saime) and made the following statement: "At that time, the purchase agreement was not legally concluded.

Subsequently, I purchased the house for 180 guruş. Hence, the house in question is my property. This is why I object to Mustafa Beşe's attempts to occupy it."

When Mustafa Beşe was asked to provide evidence of his purchase of the aforementioned house, he introduced to the court as witnesses Tayyib Ali Efendi ibn Yahya Efendi and Mehmed Efendi ibn İsmail. They testified as follows: "Four days ago, Saime agreed in our presence to sell her house to Mustafa Efendi for 180 guruş. Mustafa Efendi also agreed to purchase the house and [after the mutual agreement] left [Saime] to get the money. While he was away, Saime sold the house to Ali Beşe. We are witnesses to the fact that Saime had agreed to sell her house to Mustafa Efendi before she agreed to sell it to Ali Beşe."

After the court inspected and confirmed the reputations of the witnesses, it instructed Saime to accept Mustafa Efendi's 180 guruş and ordered Saime and Ali Beşe not to interfere with Mustafa Efendi's occupation of the house.

? Şevval 1148 / February (or March) 1736

Witnesses... ${ }^{13}$

As seen in this record, court registers provide detailed information about the identities of litigants, the evidence presented in court, and the trial outcome. Consisting of abbreviated descriptions of the litigations heard and decided in court, they typically begin by identifying the litigants through their full names, honorary titles and other distinguishing markers attached to their names, religious identities, and their places of origin. If the litigants were related to each other, this information is also provided. Afterwards, the records reveal the nature of the dispute, typically in the form of a direct quote by the individuals who approached the court, followed by their opponents' responses to the accusations directed at them. Next, the entries disclose the evidence submitted to court by the litigants, such as the full names and testimonies of the

\footnotetext{
${ }^{13}$ The case entry demonstrates the evidentiary procedures that the court followed. Since it was Mustafa Ağa who made a claim that went against the initial legal presumption (the contention that there was a contractual agreement between himself and Saime), which Ali Beşe denied, the court required Mustafa Ağa to prove his claim. He did so by providing witness testimonies, which the court accepted Consequently, the case was decided in his favor without further investigation. In this case, the defendant's (Ali Beşe) involvement in the litigation officially ended when he rejected the plaintiff's (Mustafa Ağa's) contention. As we will see later, the evidentiary procedure exemplified in this entry influenced the results of litigations.
} 
witnesses. Finally, the records show how the court decided on the dispute. Case records always contain the dates of the hearings and the names of the witnesses to proceedings.

\section{LITIGANT CATEGORIES}

We use all available information about the identities of litigants recorded in proceedings to determine the relative frequencies of various plaintiff-defendant combinations that came to court to resolve disputes in Kastamonu during this period. The data-set used in this study consists of 597 litigations heard in court. ${ }^{14}$ The characteristics of litigants that are the easiest to determine are gender and religion. The names of litigants make it easy to distinguish males from females, and court records similarly note the religious affiliation of non-Muslims in a way that makes it easy to identify them. Based on this information, Table 1 shows the proportions of various plaintiff-defendant combinations according to gender and religion. As seen in the Table, in a majority of cases (57\%) the litigants were both male, and females brought suit against males in about twice as many cases (25\%) than the other way around (13\%). The proportions of disputes involving non-Muslims was small (about 3-4\%), particularly noteworthy given that nonMuslims constituted about 15 percent of the population.

Table 1 about here

Court records also include information about family affiliation, which allows us to determine if a litigant was related to an established and prominent family. The names of these

\footnotetext{
${ }^{14}$ The Kastamonu Court records actually include 847 litigations that were heard during the three subperiods explored in this article, but we omitted 250 of these disputes because they involved multiple individuals as plaintiffs or defendants. Since we are interested in determining the effects of individual characteristics, we omitted 120 court cases in which the plaintiff consisted of multiple individuals and 130 cases in which the defendant was not a single individual. Note also that 847 cases for the entire period corresponds to an average of about three cases per month, remarkably low for a town of about 12,000 people, although this is not a something specific to Kastamonu.
} 
families appear frequently in court records, and litigants affiliated with them are identified with the suffix "zade." For example, Kıbrisi-zade Ahmed Efendi, was a member of the prominent Kıbrisi extended-family, who played important roles is the judicial and administrative affairs of the region. Although there are no published studies on the economic characteristics of these families, our own unpublished analysis of eighteenth-century probate inventories indicate that individuals who belonged to them were significantly wealthier than the rest of the society. ${ }^{15}$ As seen in Table 1, only a small proportion (about 5-6\%) of cases involved members of prominent families. We explore below whether this affiliation gave them an advantage in court.

Going beyond differences in gender, religion, and family affiliation, we can make creative use of some of the information included in court records to make inferences about other characteristics of litigants. One of the asymmetries between litigants that could affect their chances of winning in court is socioeconomic status. Although we do not have direct information on the incomes, occupations, or educational backgrounds of all litigants, court records include the honorary titles and religious markers of litigants, which can be utilized as indicators of socioeconomic status.

Honorary titles appear in court records as parts of men's names and they help to distinguish individuals according to their affiliation with the provincial administrative structure and relative positions within the community. They signify individuals who possessed specific types of professional training or education, who performed various sorts of military/administrative or judicial/religious functions, and who enjoyed the socioeconomic privileges associated therewith. In addition to exemption from taxation, these benefits included

\footnotetext{
${ }^{15}$ Based on 1,600 probate estate inventories from Kastamonu in our possession, we can surmise that zades were three to four times as wealthy as non-zades in the eighteenth century.
} 
economic compensation for specific services as well as varying degrees of communal influence due to their involvement in the provincial administration or service.

Based on honorary titles, we can determine not just whether a man belonged to the military/administrative establishment (seyfiyye, in Ottoman Turkish) or the judicial/religious one (ilmiyye) but also whether he belonged to the elite group within each category. ${ }^{16}$ For example, A $\breve{g} a$ s were the wealthiest, most prestigious, and highest-ranking members of the military/administrative establishment, and Efendis had the same status in the judicial/religious establishment (Ergene and Berker, 2008). ${ }^{17}$ These groups included individuals who collectively managed the official affairs of the town and its environs in different capacities, played communal leadership roles, and also took advantage of the economic opportunities available in their locations (Barkey, 2008, ch. 7).

Using titles as indicators of socioeconomic status, we thus divided litigants into four groups. Since titles were recorded exclusively for men, we separated female litigants into the first category. We divided male litigants into three groups based on whether they had honorific titles and whether their title indicated membership in the elite category. So the second category of plaintiffs is the "elite males," consisting of $A \breve{g} a$ s as elite military/administrative titleholders and Efendis as elite religious/judicial titleholders. The third category consists of "males with non-elite titles," and the fourth are the category of men recorded in court proceedings without

\footnotetext{
${ }^{16}$ Seyfiyye included those men with military/administrative responsibilities or affiliations, such as governors, members of the police force, and the officers as well as the rank-and-file of the provincial militia. These individuals carried the following titles: A $\breve{g} a, B e s ̧ e$, and Be $\breve{g}$. Ilmiyye, on the other hand, was composed of individuals with religious and judiciary responsibilities or affiliations, such as local magistrates, jurisconsults (muftis), and mosque imams. Such individuals carried the following titles: Efendi, Molla, Halife, Çelebi, and Dede. Other designations that indicate seyfiyye and ilmiyye affiliation accompanied the honorary titles listed in the present note.

${ }^{17}$ Ergene and Berker (2008) observe in probate estate inventories that the average wealth levels of Ağas were about two-and-a-half times as much as the average wealth levels among men in eighteenth-century Kastamonu. The average wealth levels of Efendis were about two times as much.
} 
titles. Although "males with non-elite titles" were not necessarily wealthier than title-less men we attribute a relatively higher social status to the first group, based on their public functions, professional affiliations, and networks of association (Ergene and Berker, 2008). Table 2 shows the proportions of plaintiffs and defendants in each category.

Table 2 about here

In addition identifying Muslims and non-Muslims, we can further distinguish among Muslim litigants according to their religious markers. These markers, also parts of litigants' names, demonstrate if individuals claimed descent from Muhammad (sing. seyyid for men, şerife for women) or made the pilgrimage to Mecca (sing. elhac or hacı for men, hace or haciye for women). These markers indicate elevated socio-religious status within the community, though they should not be confused with religious/judicial titles. Indeed, men with military/administrative and religious/judicial titles, as well as the tile-less men, are often identified in the court records as pilgrims and descendants of Muhammad. Previous research also demonstrated that the epithet pilgrim was associated with wealth in eighteenth century Kastamonu (Ergene and Berker, 2008), which is not surprising given the cost of conducting pilgrimage to the Hijaz from Anatolia. ${ }^{18}$ Table 3 shows the distribution of litigants according to religious markers.

Table 3 about here

\footnotetext{
${ }^{18}$ The probate estate inventories of Kastamonu indicate that the average wealth levels of the pilgrims were twice as much as average wealth levels in eighteenth century. The Descendants of Muhammad, however, were not wealthier than the rest of the population (Ergene and Berker, 2008). Unfortunately we have no wealth information on non-Muslims.
} 
As seen in Table 3, about 30\% of all cases involved an individual with a religious marker, and a high proportion of those were against litigants who did not carry such a title. We explore in more detail below whether and why these characteristics were likely to affect the plaintiff's chances of winning at trial.

\section{DETERMINANTS OF PLAINTIFF WIN RATIO}

We now turn our attention to trial outcomes and combine insights from the law and economics literature with information from Kastamonu records to examine the factors that could influence the plaintiff's chances of success in Ottoman courts. As noted above, Siegelman and Waldfogel (1999) have identified three general characteristics of the litigation environment that can affect the trial and plaintiff win ratios, namely the ability of parties to estimate the quality of their cases, the degree of stake asymmetry between parties, and the decision standard of the case type.

To see how these parameters might help to explain differences in plaintiff's chances of success in Kastamonu courts, consider first the role of parties' ability to estimate the quality of their cases. In general, this might happen when parties have asymmetric information about the law governing a case or about the facts of a dispute. Suppose, for example, that in a certain casetype plaintiffs systematically have greater ability to estimate the quality of their cases than defendants. This would mean that plaintiffs with relatively good chances at trial would likely go to trial and those with relatively weak cases would likely settle. The selection effect of differential ability would thus mean that the plaintiffs win ratio would be higher than fifty percent of cases that go to trial.

Although we do not have direct evidence on the relative abilities of parties to estimate the quality of their cases in Kastamonu courts, we can use some of the observable characteristics of 
litigants that were displayed in Tables 1-3 as proxies. To form preliminary expectations about the way these characteristics can affect the parties' chances of success in court, consider the differences in gender and title, religion and religious markers, and family affiliation displayed above. Based on our knowledge of differential access of men and women to education and economic resources in eighteenth-century Kastamonu (Ergene and Berker, 2008), we would expect men to be on average more successful than women in court, all else being the same, because individuals with higher levels of education and income would be more likely than others to either have acquired the pertinent knowledge about legal rules and facts of a dispute or have the means to acquire it from others. ${ }^{19}$ Beyond the general role of gender, however, men's chances of success could depend more importantly on their elite status. More than any other group, men with elite titles would be expected to perform well in litigations since they constituted the wealthiest group in eighteenth-century Kastamonu (Ergene and Berker, 2008). They were also highly educated and/or experienced in local administrative affairs, which involved regular interaction with the court and its personnel. In fact, a formal religious and legal education constituted the principle basis of elite religious status, and elite military title-holders similarly functioned as high-level state functionaries. Members of this group must have included the most powerful and effective individuals in Kastamonu. ${ }^{20}$ Finally, differences in religion could also be a significant factor in a suit if knowledge of the Islamic law was essential for parties to determine the quality of their cases. In such a situation, a non-Muslim could be at a relative disadvantage in determining the quality of his case if he faced a Muslim in court.

\footnotetext{
${ }^{19}$ Ergene and Berker (2008) suggest that men were, on average, three times as wealthy as women in eighteenth-century Kastamonu.

${ }^{20}$ Pilgrims and zades were also wealthier compared to those individuals without these qualities, which is why we would expect them to be successful in court.
} 
Consider next the role of asymmetric stakes on the plaintiff's chances of success at trial. Asymmetric stakes arise when one or both of the parties to a case derive some cost or benefit from the outcome that is not captured entirely by the amount of the damages to be paid by the defendant to the plaintiff in this case. This may happen, for example, if one of the parties has higher reputational concerns about the trial outcome than the other, such as when a prominent member of a society faces a relatively unknown individual. In situations of asymmetric stakes, we would expect parties with greater stakes to have a higher chance of success in cases in litigation because of a selection effect that raises the proportion of strong cases that go to trial. By altering the total cost and benefit of court outcomes, asymmetric stakes make settlement more likely in otherwise "toss-up" disputes. Since the party with greater stakes would have more to lose from litigation, he or she would be more likely to settle the dispute by making an acceptable offer to the party with lesser stake than to risk a larger loss at trial. As a result, the cases that go to trial would likely be the ones in which the party with higher stakes has a greater chance for success than would be if the stakes were the same.

We could imagine various factors that might have generated asymmetric stakes in our context. For example, among groups who played leadership roles in the community or claimed to have possessed higher levels of social and/or religious status (i.e. elite title holders, individuals with religious markers, members of prominent families), the concern to protect their reputations might have increased the stakes in a dispute, all else being the same. On the other hand, the subjective value (opportunity cost) of the cash or property subject to disputes could be higher for women than men because of fewer alternatives for employment and wealth-creation that were available to females. The stakes could similarly be high for poorer groups compared to their wealthier adversaries because of differences in alternative opportunities, which could raise their 
stakes and make them more likely to settle than go to court. Such a selection effect, therefore, could work in the opposite direction in cases involving men and women or rich elites and poorer segments of the society.

The final parameter of the litigation environment identified by Siegelman and Waldfogel (1999) as a basic determinant of the trial and plaintiff win rates is the decision standard of the subject category. Since it is the decision standard that selects the winners and losers in court cases, the standard applicable to a category of cases can affect the plaintiff win rate in that category significantly. To see this, consider differences among case types according to subject categories. Here we focus not so much on the specific identities of litigants but on the nature of the incident or behavior that led to dispute. For example, modern courts generally make a clear distinction between criminal and civil cases. Whereas the decision in the former category concerns determining whether the accused has committed a crime, the decision in civil cases is to determine whether the defendant is liable for the plaintiff's alleged injuries. Typically the latter category further consists of a variety of subcategories, such as contracts, real property, worker injury, and product liability. The distribution of disputes and the applicable decision standard may vary significantly across these categories. ${ }^{21}$

Differences among subject categories suggest that the plaintiff's chances of success might vary accordingly. Studying the proportions of plaintiff victories in civil cases tried in Cook County, Illinois, between 1959-79, Priest and Klein (1984: 38) have shown that the plaintiff win rate was very close to 50 percent in some categories (common carriers, property injuries, and dramshop cases), but it was significantly different from this benchmark in other categories

\footnotetext{
${ }^{21}$ In the context of Ottoman and Islamic legal processes, earlier research indicated variations in evidentiary standards in civil and criminal litigations (cf. Heyd, 1973; Ginio, 1988, Peters, 2005; Zarinebaf, 2011).
} 
(worker injury, product liability, and malpractice). Kessler, Meites, and Miller (1996: 238-41) and Waldfogel (1995: 240) have similarly found systematically different win rates among case types in their empirical analysis of court outcomes.

In the Ottoman case as well it is possible to identify common characteristics in the distribution of some litigations that distinguish them clearly from others. For a systematic categorization of cases heard in Kastamonu courts, we classify them into three groups according to subjects and the nature of relationship among the litigants. More specifically, we divide them into the categories of 1) criminal cases (all involving unrelated parties), 2) civil cases among related parties, and 3) civil case among unrelated parties. We separated cases that involved related parties from unrelated ones because the effect of individual characteristics on court outcomes may depend on the nature of the relationship between litigants. Our sample does not include criminal litigations involving related parties.

\section{A QUANTITATIVE ANALYSIS OF COURT TRIALS IN KASTAMONU}

As noted, our data-set consists of 597 litigations (in which both the plaintiffs and defendants were individuals) heard in the Kastamonu court during the period between 1673 and 1806. The largest group of litigations (329) involves civil disputes among unrelated parties, which largely includes contentions over money and property (debt, ownership of property, commercial disputes, etc.). The second group consists of civil disputes among related parties. There are 190 such litigations in our sample, and they are largely disputes over money and property among kin and/or family members. The last group is criminal disputes (78), consisting primarily of contentions over acts of assault (sexual and otherwise), robbery, and usurpation. 
It is interesting that plaintiffs won 45 percent (standard deviation 0.50 ) of all cases in our sample, somewhat lower than the rate of 50 percent hypothesized by Klein and Priest. The rate varied significantly, however, across the three subject categories. Whereas the plaintiff win ratio was 51 percent $(\sigma=0.50)$ in criminal cases, it was 45 percent $(\sigma=0.50)$ in civil disputes among unrelated parties and 41 percent $(\sigma=0.49)$ in those among related parties. The plaintiff win ratio also varied significantly across plaintiff-defendant combinations because of asymmetric stakes and differential abilities to estimate case quality.

Since factors representing asymmetric stakes, differential abilities, and case types likely influenced the plaintiff win ratio simultaneously, we need to use regression analysis to isolate the individual effect of each factor. The dependent variable in this analysis represents the judge's decision, a dummy variable that takes the value of 1 if the case was won by the plaintiff. We used the Probit model for estimation.

To determine factors affecting the plaintiff win ratio, we included in the analysis five categories of explanatory variables. The first three categories represent various plaintiffdefendant combinations corresponding to differences in gender and honorary titles, religion and religious markers, and family status. Each of these are dummy variables that take the value of 1 if the plaintiff-defendant combination is as stated, and 0 otherwise. As noted in Table 4, in each category the plaintiff-defendant combination with the highest proportion of the total has been omitted to avoid multicollinearity. Therefore, the coefficient of each combination needs to be interpreted as the differential effect from the omitted one.

The fourth group of variables shows the effect of case type on the plaintiff's chance of success. We used dummy variables to distinguish between criminal cases, civil cases among 
related parties, and civil cases among unrelated parties. We omitted the variable "civil cases among unrelated parties" in the regression equation to avoid multicollinearity.

Finally, we included a group of variables to control for the effect of possible unobserved changes in the decision standard over time. We divided our period into three roughly equal subperiods as follows:

1) $1095 / 1684--1110 / 1698$

2) $1148 / 1735--1156 / 1743$

3) $1195 / 1781--1204 / 1790$

The first period is slightly longer than the other two because of missing documentation for some years. The number of litigations heard in court is 167 in the first period, 183 in the second period, and 247 in the third period.

Differences among clusters of case types and periods suggest the possibility of correlation of the observations within these clusters. Criminal cases in the first period, for example, could be correlated with each other because of shared characteristics in legal procedures and regulations. To correct for the possibility of correlated data, we divided observations into nine clusters (based on the three case-types and three time-periods that were defined above) and used clustered robust standard errors in regression analysis.

The results of regression analysis, displayed in Table 4, show how differences in the abilities of parties to estimate the quality of their cases, the degree of stake asymmetry, and decision standard affected the plaintiff's chances of winning at trial (compared to those in the omitted categories) in Kastamonu during this period. Note that (in addition to omitting one of the variables in each category to avoid multicollinearity) we had to drop some variables and 
observations from the analysis because there were no corresponding observations or because they predicted success or failure perfectly.

Table 4 about here

The results generally confirm the preliminary expectations discussed above about the higher chances of elite males in court. For all matchups in which they were the plaintiffs, the coefficients of corresponding variables were generally positive and highly significant, indicating that these individuals were likely to win cases in court against all other groups. A similar result held for individuals with non-elite titles. They were likely to win in court as plaintiffs against all groups except those individuals with elite titles.

Why do we not observe a similar pattern in those cases when elite and non-elite males were defendants? The peculiarities of Islamic evidentiary procedures are relevant here. As discussed, while Islamic law recognizes the right of the müdde ' $i$ to verify her/his case, it denies the müdde ' $a$ 'aleyh the opportunity to uphold her/his own position. Since the plaintiffs were designated as the müdde iyun (pl. of müdde 'i) in most cases, they often enjoyed a potential advantage over the defendants. ${ }^{22}$ Our results suggest that in cross-group litigations elite and nonelite title-holders were more successful compared to less privileged parties (other male and female litigants from the vantage point of elite men; title-less men and females from the perspective of non-elite title-holders) in taking advantage of Islamic evidentiary standards as plaintiffs. In other words, they were more likely to bring to court cases in which they would be designated as müdde iyun, and if/when this happened, in providing credible evidence to prove their claims. However, when they faced other groups as defendants and, therefore, often lacked

\footnotetext{
${ }^{22}$ See note 12 .
} 
the advantage associated with the müdde' $i$ position, elite and non-elite title-holders could not win their cases as often.

Expectations about how the women fared against different groups of men would depend on the relative importance of their possibly lower abilities to estimate the quality of their cases and in their possibly higher stakes in losing a case, and our results reflect these conditions. Although the coefficient was not significant at conventional levels for women as plaintiffs against males with (elite or non-elite) titles, it was positive and significant when they were plaintiffs against males with no titles. ${ }^{23}$ The latter result might suggest that differential stakes from the outcome likely offset any disadvantage that women may have had in their abilities to estimate case quality due to lower levels of education and experience when they went to court against men with no titles. $^{24}$

The results also provide partial support for the arguments made above about the way religion and religious markers would be expected to affect the plaintiff's chances at trial. One has to be careful in generalizing these results, however, because the number of observations is either zero or too small in some of these categories. The results clearly show the relative advantages of pilgrim Muslims against other groups as plaintiffs or defendants. ${ }^{25}$ Compared to cases involving two Muslims with no religious markers in court, individuals marked as pilgrims were generally likely to win both as plaintiffs and defendants against other groups. ${ }^{26}$ But the coefficients were

\footnotetext{
${ }^{23}$ According to Ergene and Berker (2008), title-less men were about twice as wealthy as women.

${ }^{24}$ When we ignore the differences among men in elite and title-holding status and run the same regression with just males and females as litigants (omitting the category of both litigants as males), the results show that male plaintiffs were likely to win against females.

${ }^{25}$ As indicated, the pilgrim label was also a sign of economic status.

${ }^{26}$ For reasons explained in text, winning a case as a defendant must have been more difficult than winning it as a plaintiff. This outcome generally indicates that either a) the plaintiff was not able to prove his/her case by credible evidence, if s/he was designated by court as the müdde ' $i$, or $b$ ) the defendant was
} 
mostly insignificant for descendants of Prophet Muhammad, other Muslims with no markers, and non-Muslims, indicating that membership in these groups as plaintiffs did not generate significant differences from others in stakes or in their abilities to estimate the quality of their cases.

The variables in the final three categories show the effects of family status and variations in standards over time and across case-categories. The results provide some support (at the $10 \%$ level) to the expectation that members of prominent families did well against other individuals (compared to cases that involved members of non-prominent individuals as litigants), showing the advantage that family affiliation contributed to their chances of winning in court as plaintiffs. The coefficients and standard errors of variables that control for possible differences in casetypes and time-periods indicate significant differences over time but not across case types.

\section{CONCLUSION}

We offer a quantitative analysis of court cases from the late seventeenth- and eighteenth-century Ottoman Kastamonu to determine how gender and elite status, religion and religious markers, and temporal and categorical variations in the decision standard influenced the results of cases heard and decided in an Islamic court. To put our analysis in context, we used insights from the law and economics literature and interpreted individual characteristics as indicators of differential abilities in estimating the quality of suits and the degree of stake asymmetry between litigants. The results show that elite males generally had high chances of success as plaintiffs against females and against other males with no titles or non-elite titles, and that members of

able to assume the position of the müdde $i$ by making a counter-claim against the plaintiff, and then by proving her/his story by providing credible evidence. The ability to predict the likelihood of the first possibility must have required some experience in legal processes. Managing to accomplish the second possibility must have required both legal experience and prior preparation. 
prominent families did similarly well against other individuals. Overall these results indicate that affluent and socially prominent litigants, presumably more informed than others about legal rules and procedures, performed well against their poorer and less prominent opponents, when the former group acted as plaintiffs. The results were more balanced when privileged groups faced less advantaged ones as defendants. Our results also show that women were likely to win against men with no titles (but not against men with titles) and that pilgrims were generally likely to win both as plaintiffs and defendants against other groups. The latter results might be interpreted to suggest that the court outcome was also influenced by asymmetric stakes between males and females and between pilgrims and others.

Our results challenge some of the widely held presumptions about dispute resolution in Ottoman courts. Contrary to Weber's claim, the judges' decisions were far from arbitrary. Kastamonu judges made decisions that can be grasped by the tools and concepts of modern scholarship on dispute resolution, and their decisions displayed systematic patterns that are consistent with those identified by quantitative analysis of court outcomes in modern societies. The litigants in Kastamonu courts in the seventeenth and eighteenth centuries did not seem to have faced the systemic uncertainty or the extraordinary arbitrariness that was assumed by Weber and his followers. The results also challenge the widely-shared perception in Ottoman legal scholarship that the court may have subscribed to an egalitarian legal ideology. Contrary to presumptions, based largely on impressionistic observations, that judges protected or favored the interests of the poor and the underprivileged, trial outcomes were neither impartial to the individual characteristics of litigants nor did they systematically favor the women or the title-less or non-elite men against the more privileged elites. 


\section{WORKS CITED}

Agmon, Iris (2005). Family and Court: Legal Culture and Modernity in Late Ottoman Palestine (Syracuse: Syracuse University Press).

Barkey, Karen (1994). Bandits and Bureaucrats: the Ottoman Route to State Centralization (Ithaca, N.Y.: Cornell University Press).

Barkey, Karen (2008). Empire of Difference: The Ottomans in Comparative Perspective (Cambridge: Cambridge University Press).

Cohen, Amnon (1994). A World Within: Jewish Life as Reflected in Muslim Court Documents from the Sijill of Jerusalem (Pennsylvania: Centre for Judaic Studies).

Cooter, Robert D. and Daniel L. Rubinfeld (1989). "Economic Analysis of Legal Disputes and Their Resolution,” Journal of Economic Literature 27, 1067-97.

Ergene, Boğaç A. (2003). Local Court, Provincial Society and Justice in the Ottoman Empire; Legal Practice and Dispute Resolution in Çankırl and Kastamonu. Boston and Leiden: Brill

Ergene, Boğaç A. (2008). "Social Identity and Patterns of Interaction in the Sharic a Court of Kastamonu (1740-44).” Islamic Law and Society 15, 20-54.

Ergene, Boğaç A. and Ali Berker (2008). "Wealth and Inequality in $18^{\text {th }}$ century Kastamonu: Observations for the Muslim Majority.” International Journal of Middle East Studies 40, $23-46$.

Gerber, Haim (1988). Economy and Society in an Ottoman City: Bursa, 1600-1700 (Jerusalem: The Hebrew University of Jerusalem). 
Gerber, Haim (1994). State, Society and Law in Islam: Ottoman Law in Comparative Perspective (Albany: State University of New York Press).

Ginio, Eyal (1988). "The Administration of Criminal Justice in Ottoman Selanik (Salonica) during the Eighteenth Century.” Turcica 30, 185-209.

Glaeser, Edward and Andrei Schleifer (2002). "Legal Origins," Quarterly Journal of Economics 117, 1193-1230.

Hanna, Nelly (1995). “Administration of Courts in Ottoman Cairo" in N. Hanna (ed.), The State and Its Servants (Cairo: American University Press), 44-59.

Heyd, Uriel (1973). Studies in Ottoman Criminal Law (Oxford: Clarendon Press).

Heywood, Colin (1978). “Kastamonu.” Encyclopedia of Islam, 2nd ed. Leiden: E. J. Brill. Vol 4, 738.

İnalcık, Halil (1986). "Mahkama.” Encyclopedia of Islam $2^{\text {nd }}$ ed. Leiden: E.J. Brill. vol. 6, 2-4. İnalcık, Halil (1988). “Şikayet Hakkı: ‘Arz-1 Hal ve `Arz-1 Mahzar'lar.” Osmanlı Araşstırmaları 7-8, 33-45.

İslamoğlu-İnan, Huri (1994). State and Peasant in the Ottoman Empire: Agrarian Power Relations and Regional Economic Development in Ottoman Anatolia during the Sixteenth Century (Leiden; New York: E.J. Brill).

Jennings, Ronald C. (1978). "Kad1, Court, and Legal Procedure in $17^{\text {th }}$ C. Ottoman Kayseri," Studia Islamica 48, 133-72.

Jennings, Ronald C. (1979). "Limitations of the Judicial Powers of Qadi in $17^{\text {th }}$ C. Ottoman Kayseri," Studia Islamica 50, 151-84. 
Johnson, Paul (1993). "Small Debts and Economic Distress in England and Wales, 1857-1913" Economic History Review 46, 65-87.

Kessler, Daniel, Thomas Meites, and Geoffrey P. Miller (1996) "Explaining Deviations from the Fifty-Percent Rule: A Multimodal Approach to the Selection of Cases for Litigation" Journal of Legal Studies, 25, 233-259.

Khan, B. Z. (2000). "Commerce and Cooperation: Litigation and Settlement of Civil Disputes on the Australian Frontier, 1860-1900" Journal of Economic History 60 1088-1119.

Kuran, Timur and Scott Lustig (2012). "Judicial Biases in Ottoman Istanbul: Islamic Justice and Its Compatibility with Modern Economic Life." Journal of Law and Economics 55, forthcoming.

La Porta, Rafael, Florencio Lopez-de-Silanes, Andrei Shleifer, and Robert W. Vishny (1998). “Law and Finance,” Journal of Political Economy 106, 1131-1150.

Ma, Debin and Jan Luiten van Zanden (2011). Law and Long-Term Economic Change (Stanford: Stanford University Press).

Meshal, Reem (2010). “Anatgonistic Sharī'as and the Construction of Orthodoxy in SixteenthCentury Ottoman Cairo.” Journal of Islamic Studies. 21: 2, 183-212.

Miceli, Thomas J. (2009). The Economic Approach to Law, second edition (Stanford: Stanford University Press).

Muldrew, Craig. (1993). "Credit and the Courts: Debt Litigation in a Seventeenth-Century Urban Community" Economic History Review, 46(1): 23-38.

Peirce, Leslie (2003). Morality Tales: Law and Gender in the Ottoman Court of Aintab (Berkeley: University of California Press). 
Peters, Rudolph (2005). Crime and Punishment in Islamic Law: Theory and Practice from the Sixteenth to the Twenty-First Century (Cambridge Cambridge University Press.

Powers, David (2002). Law, Society and Culture in the Maghrib, 1300-1500. (Cambridge: Cambridge University Press).

Priest, George L. and Benjamin Klein (1984). "The Selection of Disputes for Litigation," Journal of Legal Studies, 13, 1-55.

Siegelman, Peter and Joel Waldfogel (1999). "Toward a Taxonomy of Disputes: New Evidence through the Prism of the Priest/Klein Model" Journal of Legal Studies 28, 101-130.

Singer, Amy (1994). Palestinian Peasants and Ottoman Officials: Rural Administration around Sixteenth-Century Jerusalem (Cambridge, New York: Cambridge University Press).

Weber, Max (1978). Economy and Society: An Outline of Interpretive Sociology. Berkeley: University of California Press.

Waldfogel, Joel. (1995). "The Selection Hypothesis and the Relationship between Trial and Plaintiff Victory" Journal of Political Economy 103, 229-260.

Zarinebaf, Fariba (2011). Crime and Punishment in Istanbul: 1700-1800 (Berkeley: University of California Press). 
Table 1

Proportions of Cases According to the Gender, Religion, and Family Affiliation of Litigants (percent)

\begin{tabular}{|c|c|c|c|c|c|c|c|}
\hline & \multicolumn{6}{|c|}{ Defendant } \\
\hline & & Male & Female & Muslim & $\begin{array}{l}\text { Non- } \\
\text { Muslim }\end{array}$ & $\begin{array}{c}\text { Member of } \\
\text { Prominent } \\
\text { Family }\end{array}$ & $\begin{array}{c}\text { Member of } \\
\text { non- } \\
\text { Prominent } \\
\text { Family }\end{array}$ \\
\hline \multirow{6}{*}{ 常. } & Male & 57 & 13 & & & & \\
\hline & Female & 25 & 6 & & & & \\
\hline & Muslim & & & 97 & 1 & & \\
\hline & Non-Muslim & & & 1 & 2 & & \\
\hline & $\begin{array}{c}\text { Member of } \\
\text { Prominent } \\
\text { Family }\end{array}$ & & & & & 0.3 & 3 \\
\hline & $\begin{array}{l}\text { Member of } \\
\text { non- } \\
\text { Prominent } \\
\text { Family }\end{array}$ & & & & & 3 & 95 \\
\hline
\end{tabular}

Source: Court records (sicils) of Kastamonu. See the text for definitions of categories. 


\section{Table 2}

Gender, Honorary Titles and Elite Status of Litigants

\begin{tabular}{|c|c|c|c|c|c|}
\hline & & \multicolumn{4}{|c|}{ (percent of all cases) } \\
\hline & & \multicolumn{4}{|c|}{ Defendant } \\
\hline & & Female & Elite Male & $\begin{array}{l}\text { Non- } \\
\text { Elite } \\
\text { Male }\end{array}$ & $\begin{array}{l}\text { Male } \\
\text { with no } \\
\text { Title }\end{array}$ \\
\hline \multirow{4}{*}{ 䆡. } & Female & 6 & 2 & 9 & 14 \\
\hline & Elite Male & 2 & 3 & 4 & 4 \\
\hline & $\begin{array}{l}\text { Non-Elite } \\
\text { Male }\end{array}$ & 4 & 3 & 9 & 6 \\
\hline & $\begin{array}{l}\text { Male with } \\
\text { no Title }\end{array}$ & 6 & 3 & 10 & 16 \\
\hline
\end{tabular}

Source: Court records (sicils) of Kastamonu. See the text for definitions of elite status based on honorary titles. 
Table 3

Religion and Religious Markers of Litigants (percent)

\begin{tabular}{|c|c|c|c|c|c|}
\hline & & \multicolumn{4}{|c|}{ Defendant } \\
\hline & & $\begin{array}{l}\text { Non- } \\
\text { Muslim }\end{array}$ & $\begin{array}{l}\text { Muslim, } \\
\text { Pilgrim }\end{array}$ & $\begin{array}{l}\text { Muslim, } \\
\text { Descendant } \\
\text { of Prophet } \\
\text { Mohammad }\end{array}$ & $\begin{array}{l}\text { Muslim, } \\
\text { No } \\
\text { Religious } \\
\text { Marker }\end{array}$ \\
\hline \multirow{4}{*}{ 兽. } & $\begin{array}{l}\text { Non- } \\
\text { Muslim }\end{array}$ & 2 & 0 & 0 & 1 \\
\hline & $\begin{array}{l}\text { Muslim, } \\
\text { Pilgrim }\end{array}$ & 0 & 2 & 0 & 5 \\
\hline & $\begin{array}{l}\text { Muslim, } \\
\text { Descendant } \\
\text { of Prophet } \\
\text { Mohammad }\end{array}$ & 0 & 0 & 2 & 6 \\
\hline & $\begin{array}{l}\text { Muslim, } \\
\text { No } \\
\text { Religious } \\
\text { Marker }\end{array}$ & 0 & 7 & 6 & 70 \\
\hline
\end{tabular}

Source: Court records (sicils) of Kastamonu. See the text for definitions of religious markers. 
Table 4

Probit Analysis of Influences on Plaintiff's Chances of Success at Trial

\begin{tabular}{|c|c|c|c|c|}
\hline CATEGORY & PLAINTIFF & DEFENDANT & $\begin{array}{l}\text { COEFFI } \\
\text { CIENT }\end{array}$ & \begin{tabular}{|l|} 
ST. \\
ERROR
\end{tabular} \\
\hline \multirow{16}{*}{ 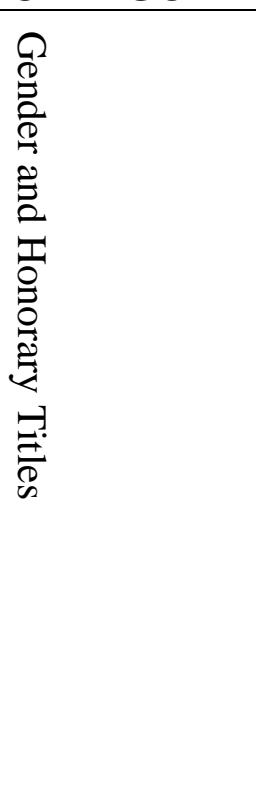 } & Male, No Title & Male, No Title & \multicolumn{2}{|c|}{ omitted } \\
\hline & Female & Female & 0.26 & 0.22 \\
\hline & Female & Elite Male & -0.06 & 0.29 \\
\hline & Female & Male, non-Elite Title & 0.29 & 0.24 \\
\hline & Female & Male, No Title & $0.35^{* * *}$ & 0.14 \\
\hline & Elite Male & Female & $1.27 * * *$ & 0.33 \\
\hline & Elite Male & Elite Male & $0.94 * *$ & 0.42 \\
\hline & Elite Male & Male, non-Elite Title & $1.36^{* * *}$ & 0.33 \\
\hline & Elite Male & Male, No Title & $1.08^{* * *}$ & 0.24 \\
\hline & Male, non-Elite Title & Female & $0.62 * *$ & 0.28 \\
\hline & Male, non-Elite Title & Elite Male & 0.47 & 0.38 \\
\hline & Male, non-Elite Title & Male, non-Elite Title & $0.77 * * *$ & 0.25 \\
\hline & Male, non-Elite Title & Male, No Title & $0.65^{* * *}$ & 0.27 \\
\hline & Male, No Title & Female & 0.19 & 0.16 \\
\hline & Male, No Title & Elite Male & 0.24 & 0.44 \\
\hline & Male, No Title & Male, non-Elite Title & $0.33^{*}$ & 0.23 \\
\hline \multirow{14}{*}{ 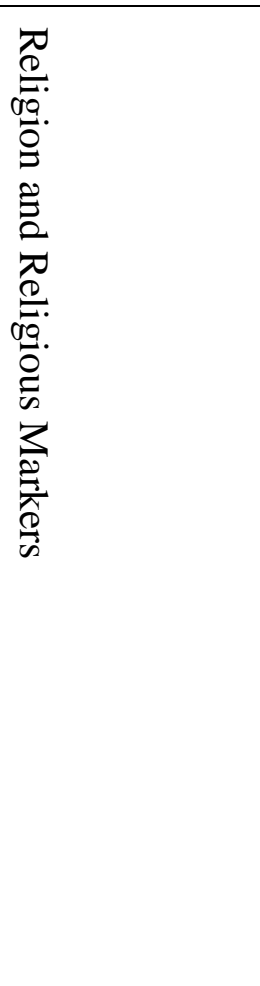 } & Muslim, No Marker & Muslim, No Marker & \multicolumn{2}{|l|}{ omitted } \\
\hline & Muslim, Pilgrim & Muslim, Pilgrim & 0.28 & 0.52 \\
\hline & Muslim, Pilgrim & Descendant of Muhammad & \multicolumn{2}{|c|}{$\begin{array}{l}\text { predicts success } \\
\text { perfectly (2) }\end{array}$} \\
\hline & Muslim, Pilgrim & Non-Muslim & \multicolumn{2}{|c|}{$\begin{array}{l}\text { predicts success } \\
\text { perfectly (1) }\end{array}$} \\
\hline & \begin{tabular}{|l|} 
Muslim, Pilgrim \\
\end{tabular} & Muslim, No Marker & $0.76^{* * * *}$ & 0.31 \\
\hline & Descendant of Muhammad & Muslim, Pilgrim & \multicolumn{2}{|c|}{$\begin{array}{l}\text { predicts failure } \\
\text { perfectly (1) }\end{array}$} \\
\hline & Descendant of Muhammad & Descendant of Muhammad & -0.15 & 0.36 \\
\hline & Descendant of Muhammad & Non-Muslim & \multicolumn{2}{|c|}{$\begin{array}{l}\text { dropped due to } \\
\text { collinearity }(0)\end{array}$} \\
\hline & Descendant of Muhammad & Muslim, No Marker & 0.11 & 0.14 \\
\hline & Non-Muslim & Muslim, Pilgrim & \multicolumn{2}{|c|}{$\begin{array}{l}\text { predicts failure } \\
\text { perfectly (1) }\end{array}$} \\
\hline & Non-Muslim & Descendant of Muhammad & \multicolumn{2}{|c|}{$\begin{array}{l}\text { dropped due to } \\
\text { collinearity }(0)\end{array}$} \\
\hline & Non-Muslim & Non-Muslim & $0.69^{*}$ & 0.53 \\
\hline & Non-Muslim & Muslim, No Marker & -0.12 & 0.39 \\
\hline & Muslim, No Marker & Muslim, Pilgrim & -0.26 & 0.36 \\
\hline
\end{tabular}




\begin{tabular}{|c|c|c|c|c|}
\hline & Muslim, No Marker & Descendant of Muhammad & -0.10 & 0.14 \\
\hline & Muslim, No Marker & Non-Muslim & 0.38 & 0.97 \\
\hline \multirow[b]{4}{*}{ Family Status } & Non-Prominent & Non-Prominent & \multicolumn{2}{|l|}{ Omitted } \\
\hline & Prominent & Prominent & \multicolumn{2}{|c|}{$\begin{array}{l}\text { predicts success } \\
\text { perfectly (2) }\end{array}$} \\
\hline & Prominent & Non-Prominent & $0.16^{*}$ & 0.10 \\
\hline & Non-Prominent & Prominent & -0.32 & 0.46 \\
\hline \multirow[b]{3}{*}{ Case Category } & \multicolumn{2}{|c|}{ Civil Dispute among Unrelated Parties } & \multicolumn{2}{|l|}{ Omitted } \\
\hline & \multicolumn{2}{|c|}{ Criminal Case } & 0.25 & 0.25 \\
\hline & \multicolumn{2}{|c|}{ Civil Dispute among Related Parties } & 0.18 & 0.14 \\
\hline \multirow[b]{3}{*}{ Time Period } & \multicolumn{2}{|l|}{$1684-98$} & \multicolumn{2}{|l|}{ Omitted } \\
\hline & \multicolumn{2}{|l|}{$1698-1743$} & $-0.22 * *$ & 0.11 \\
\hline & \multicolumn{2}{|l|}{$1781-1790$} & $-0.56 * * *$ & 0.11 \\
\hline \multicolumn{3}{|l|}{ Constant } & $-0.42 * * *$ & 0.12 \\
\hline \multicolumn{3}{|l|}{$\mathrm{N}$} & 590 & \\
\hline \multicolumn{3}{|l|}{ Pseudo $\mathrm{R}^{2}$} & 0.10 & \\
\hline \multicolumn{3}{|l|}{$\begin{array}{l}\text { Log pseudo- } \\
\text { likelihood }\end{array}$} & -364.4 & \\
\hline
\end{tabular}

Source: Court records (sicils) of Kastamonu. See the text for definitions of variables.

Notes:

a. The dependent variable takes the value of 1if the case was won by the plaintiff.

b. Standard errors have been adjusted for clustering on case-type and time-period.

c. For variables that were dropped due to collinearity or predict success or failure perfectly, the number in parentheses is the number of dropped observations for which this is true.

d. $* * *$ indicates significance at $1 \%, * *$ at $5 \%$, and $*$ at $10 \%$ for a one-tailed test. 